\title{
Immortalization of pancreatic stellate cells as an in vitro model of pancreatic fibrosis: deactivation is induced by matrigel and $\mathrm{N}$-acetylcysteine
}

\author{
Ralf Jesnowski ${ }^{1,2}$, Daniel Fürst ${ }^{2}$, Jörg Ringel ${ }^{1,2}$, Ying Chen ${ }^{1,2}$, Andrea Schrödel ${ }^{1,2}$, \\ Jörg Kleeff ${ }^{3}$, Armin Kolb ${ }^{3}$, Wolfgang D Schareck ${ }^{4}$ and Matthias Löhr ${ }^{1,2}$ \\ ${ }^{1}$ Clinical Cooperation Unit Molecular Gastroenterology, DKFZ, Heidelberg, Germany; ${ }^{2}$ Department of \\ Medicine II, Medical Faculty Mannheim, University of Heidelberg, Mannheim, Germany; ${ }^{3}$ Department of \\ Surgery, University of Heidelberg, Heidelberg, Germany and ${ }^{4}$ Department of Surgery, University of Rostock, \\ Rostock, Germany
}

\begin{abstract}
Tissue fibrosis is one of the characteristics of chronic pancreatitis and pancreatic adenocarcinoma. Activated pancreatic stellate cells (PSC) play a central role in this process. However, analysis of the molecular mechanisms leading to PSC activation is hampered by the lack of an established human PSC line. To overcome this problem, we immortalized and characterized primary human PSC. The cells were isolated by the outgrowth method and were immortalized by transfection with SV40 large T antigen and human telomerase (hTERT). Primary human PSC served as controls. An immortalized line, RLT-PSC, was analyzed for the expression of stellate cell markers. Moreover, the effects of transforming growth factor $\beta$ 1(TGF $\beta 1$ ) or platelet-derived growth factor stimulation and of cultivation on basement membrane components or $\mathrm{N}$-acetylcysteine (NAC) treatment on gene and protein expression and proliferation were analyzed. Immortal RLT-PSC cells retained the phenotype of activated PSC proven by the expression of $\alpha$-smooth muscle actin ( $\alpha$ SMA), vimentin, desmin and glial fibrillary acidic protein (GFAP). TGF $\beta 1$ treatment upregulated the expression of $\alpha$ SMA, collagen type I (Col I), fibronectin and TGF $\beta$ 1. Incubation of RLT-PSC cells and primary human activated PSC on Matrigel plus NAC treatment resulted in a deactivated phenotype as evidenced by a decrease of $\alpha S M A$, connective tissue growth factor and $\mathrm{Col} I$ expression and by a decreased proliferation of the cells. Moreover, this treatment restored the ability of the cells to store vitamin A in cytoplasmic vesicles. In conclusion, we have established an immortal pancreatic stellate cell line, without changing the characteristic phenotype. Importantly, we were able to demonstrate that besides soluble factors, the matrix surrounding PSC plays a pivotal role in the maintenance of the activation process of PSC. Cultivation of activated PSC on a reconstituted basement membrane plus treatment with NAC was able to deactivate the cells, thus pointing to the possibility of an antifibrosis therapy in chronic pancreatitis.
\end{abstract}

Laboratory Investigation (2005) 85, 1276-1291. doi:10.1038/labinvest.3700329; published online 15 August 2005

Keywords: pancreas; fibrosis; pancreatic stellate cells; activation; therapy

Tissue fibrosis is one of the pathophysiological characteristics of chronic pancreatitis and pancreatic adenocarcinoma, here termed desmoplasia. ${ }^{1-4}$ In liver cirrhosis, hepatic stellate cells (HSC) have been identified to be the main source of extracellular

Correspondence: Dr R Jesnowski, PhD, Clinical Cooperation Unit Molecular Gastroenterology (E180), DKFZ (German Cancer Research Center), Im Neuenheimer Feld 280, 69120 Heidelberg, Germany.

E-mail: r.jesenofsky@DKFZ.de

Received 31 March 2005; revised and accepted 5 July 2005; published online 15 August 2005 matrix (ECM) deposition. ${ }^{5-7}$ Similarly, the recently identified pancreatic stellate cells (PSC) have been implicated in the development of fibrotic tissue in the pancreas in chronic pancreatitis and in pancreatic cancer. ${ }^{8-12}$ Moreover, these cells seem to contribute to tissue regeneration after acute necrotizing pancreatitis. ${ }^{13}$

In the normal pancreas, stellate cells are quiescent and, like their counterparts in the liver, store vitamin $\mathrm{A}$ in lipid droplets in their cytoplasm..$^{9,14}$ When exposed to injury, inflammation or after prolonged cultivation in vitro, the cells transform to an activated myofibroblast-like state. In this 
activated state, PSC begin to proliferate and synthesize ECM components like collagen type I and III (Col I and Col III), fibronectin (FN) and laminin. This state is associated with a gradual loss of lipid droplets and the expression of the proteins desmin, vimentin, $\alpha \mathrm{SMA}$ and glial fibrillary acidic protein (GFAP). ${ }^{8,9}$ A variety of factors, which contribute to this activation process, have been identified so far. These include cytokines (eg IL-1), growth factors (PDGF, TGF $\beta 1$ ), ethanol and acetaldehyde. ${ }^{11,15,16}$ Platelet-derived growth factor (PDGF) seems to be the most potent mitogen, whereas transforming growth factor $\beta 1$ (TGF $\beta 1$ ) predominantly induces matrix synthesis. ${ }^{15,17}$

Different methods for isolation of these cells have been published, using either dispersed acini, enzymatic tissue digestion and density centrifugation, or outgrowth of PSC from pancreatic tissue. ${ }^{18,8,9,19}$ These methods need fairly large amounts of tissue to obtain a sufficient number of cells. Moreover, due to the finite lifespan of PSC and the phenotypic changes observable with time in culture, researchers need to analyze different preparations of PSC, making a direct comparison of results difficult. To overcome these problems, several rat pancreatic stellate cell lines have been established, demonstrating the need of appropriate in vitro models. ${ }^{20-22}$

However, an immortalized human PSC line was not available up to now. We immortalized and characterized a human pancreatic stellate cell line without changing the characteristic phenotype of activated PSC, namely the expression of marker proteins and the responsiveness to stimuli implicated in pancreatic fibrosis. Moreover, to test the usefulness of our cell line, we analyzed the effect of culture conditions and compounds shown to exert antifibrotic effects on HSC in our in vitro system, using native human PSC as controls.

\section{Materials and methods}

\section{Isolation and Culture of Primary Pancreatic Cells}

Human pancreatic tissue was obtained from resection specimens of patients with chronic pancreatitis. Informed consent was obtained prior to surgery to use the tissue for scientific purposes. Primary human pancreatic cells used for transfection and human PSC used for control purposes were isolated by the outgrowth method. ${ }^{9,23}$ In brief, small tissue blocks $\left(1-2 \mathrm{~mm}^{3}\right)$ were cut using a scalpel and were seeded (8-10 blocks/dish) on $60-\mathrm{mm}$ Petri dishes in a small volume of culture medium (500 $\mu \mathrm{l} /$ $60 \mathrm{~mm}$ dish). After the clumps had been incubated in a humidified incubator for an hour in order to get attached, an additional $2 \mathrm{ml}$ of culture medium (Gibco Keratinocyte SFM supplemented with $5 \mathrm{ng} / \mathrm{ml}$ epidermal growth factor (EGF), $50 \mu \mathrm{g} /$ $\mathrm{ml}$ bovine pituitary extract (BPE), $50 \mu \mathrm{g} / \mathrm{ml}$ Gentamycin, $0.25 \mu \mathrm{g} / \mathrm{ml}$ Fungizone in the case of cells used for transfection; DMEM/F12 supplemented with 15\% FCS plus antibiotics in the case of primary stellate cells) was added carefully. ${ }^{23,24}$ Medium was changed every 2 days. Starting day 3 , cells were able to grow out of the tissue clumps. Cultures were kept until the colonies reached a diameter of about $10 \mathrm{~mm}$. Then the tissue clumps were removed with a pipette tip and transferred to a new culture dish for a second round of outgrowth. Cells growing out from the tissue blocks were either transfected or, in the case of PSC, expanded and passaged using trypsin/ EDTA. PSC used as controls for the experiments were in passages $3-6$.

\section{Immortalization with SV 40 Large T and hTERT}

SV40 large $\mathrm{T}$ antigen has been used for immortalization in a variety of cells; however, the immortalization frequency is very low when using SV40 large $\mathrm{T}$ alone. ${ }^{25-27}$ It has been reported that the use of SV40 large $\mathrm{T}$ in conjunction with hTERT, the catalytic subunit of the human telomerase (hTERT), increases the likelihood of immortalization. ${ }^{28}$ For this reason, the outgrown cells were transfected as described before by the Ca-phosphate-method or with FuGene reagent (Roche) using the plasmid pSV3neo and pRC/hTERT, coding for SV40 large T antigen and the catalytic subunit of the hTERT, respectively. ${ }^{29,30}$ These plasmids also carry the neomycin-resistance gene, which enables selection with G 418. Cells were selected with G 418 (Life Technologies, $300 \mu \mathrm{g} / \mathrm{ml}$ ) for at least 4 weeks, and resistant clones were expanded until the cells reached terminal crisis. Clones surviving this crisis were further expanded and characterized. After crisis, fibroblastoid clones were cultured in DMEM plus $10 \%$ FCS and antibiotics. The characterization of a fibroblastoid clone, designated RLT-PSC, started after it was cultured intermittently for 2 years at about passage number 20. In general, the cells were seeded from liquid nitrogen stocks and used for the experiments for the following 5-6 passages, before fresh cells from the seeding stocks were used.

\section{Karyotype Analysis}

SV40 large and small $\mathrm{T}$ antigens are known to induce karyotype alterations in transfected cells. In order to analyze changes of the karyotype in RLT-PSC cells, chromosome preparation was performed as previously described. ${ }^{24}$ Colcemide (final concentration $0.6 \mu \mathrm{g} / \mathrm{ml}$; Gibco) was added to the culture for $2 \mathrm{~h}$. Thereafter, the cells were incubated in a hypotonic solution $(0.075 \mathrm{M} \mathrm{KCl})$ for $15 \mathrm{~min}$, fixed twice with methanol:acetic acid (3:1, 15 min each). The resulting cell suspension was added in drops to the cold wet slides, air-dried and Giemsa stained. 


\section{Growth in Soft Agar}

Cells were mixed with an equal volume of prewarmed $0.6 \%$ agarose (Biozym) in DMEM/F12 supplemented with $10 \%$ FCS and plated onto a sublayer of $0.5 \%$ agarose in the same medium. After solidification, the gel was covered with culture medium. ${ }^{24}$ The formation of colonies was observed for 4 weeks.

\section{RNA Isolation, RT-PCR and Real-Time Quantitative RT-PCR}

For RNA preparation, the cells grown in $60-\mathrm{mm}$ Petri dishes were washed with PBS. After complete removal of the PBS, $350 \mu \mathrm{l}$ buffer RLT (Qiagen, RNeasy Mini Kit) plus $\beta$-mercapto ethanol $(\beta$-ME) $(10 \mu \mathrm{l} / \mathrm{ml})$ were pipetted directly onto the cells. The lysate was processed further according to the manufacturer's recommendations. Isolated total RNA ( $1 \mu \mathrm{g}$, determined photometrically) was reverse transcribed using Superscript II (Invitrogen, Karlsruhe, Germany) reverse transcriptase and oligo-dT primers, and the resulting cDNA was amplified in separate tubes using Hot Star Taq (Qiagen). Primers used were as shown in Table 1. The cycling parameters were as follows: initial denaturation and Taq polymerase activation at $94^{\circ} \mathrm{C}$ for $15 \mathrm{~min}$, cycling at $94^{\circ} \mathrm{C}$ for $45 \mathrm{~s}, 60^{\circ} \mathrm{C}$ for $45 \mathrm{~s}$ and $72^{\circ} \mathrm{C}$ for $1 \mathrm{~min}$ and a final extension at $72^{\circ} \mathrm{C}$ for $5 \mathrm{~min}$. The cycle number for the respective genes is outlined in Table 1.

Real-time RT-PCR with the Light Cycler system (Roche) and Sybr green was used to quantify the expression of Col I, $\alpha S M A$ and TGF $\beta 1$ after stimulation of the cells with TGF $\beta 1(5 \mathrm{ng} / \mathrm{ml})$ for $4 \mathrm{~h}$ in serum-free DMEM. Expression of these genes was normalized to that of the housekeeping gene RPL13A. ${ }^{31}$ Serial dilutions of HeLa calibrator cDNA in the range of $1 \times 10^{-2}$ to $1 \times 10^{-8}$ were used to generate standard curves of the respective genes. Amplification was performed in a volume of $20 \mu \mathrm{l}$ with a ready-to-use reaction mix (LightCycler DNA Master Sybr Green I-Kit, Roche) using $1 \mu \mathrm{l}$ or $3 \mu \mathrm{l}$ cDNA as template for the genes RPL13A, $\alpha S M A$ and $T G F \beta 1$ or $C o l$ I, respectively. Primers were used at a final concentration of $0.5 \mu \mathrm{M}, \mathrm{MgCl}_{2}$ at $2 \mathrm{mM}$. PCR consisted of an initial denaturation step at $95^{\circ} \mathrm{C}$ for $30 \mathrm{~s}$, followed by 40 cycles of $95^{\circ} \mathrm{C}$ for $0 \mathrm{~s}, 59^{\circ} \mathrm{C}$ for $10 \mathrm{~s}\left(61^{\circ} \mathrm{C}\right.$ for $\left.\mathrm{Col} \mathrm{I}\right)$ and $72^{\circ} \mathrm{C}$ for $10 \mathrm{~s}$. To increase the specificity, a melting curve analysis between 65 and $95^{\circ} \mathrm{C}$ was employed.

\section{Western Blot Analysis and Immunocytochemistry}

In order to analyze secretion of matrix proteins induced by TGF $\beta 1$ challenge, the cells were incubated in equal volumes of serum-free culture medium with or without addition of TGF $\beta 1$ for $24 \mathrm{~h}$. Subsequently, the conditioned media were harvested and the cells were trypsinized and counted. The conditioned media were mixed with SDS-sample buffer, boiled for $5 \mathrm{~min}$ and volumes corrected for the cell number were analyzed either for Col I expression using a dot blot apparatus (Biorad) or FN expression via Western blot.

Whole-cell lysates were prepared by incubating the cells with denaturing Laemmli buffer. Proteins were separated by SDS-PAGE and transferred to a polyvinylidene difluoride membrane (Roche) using standard protocols. ${ }^{24}$

Table 1 Primers used for RT-PCR gene expression analysis

\begin{tabular}{|c|c|c|}
\hline \multirow[t]{2}{*}{$\alpha \mathrm{SMA}$} & F-TTC AAT GTC CCA GCC ATG TA & 29 cycles \\
\hline & R-GGA AAC GTT CAT TTC CGA TG & Product size $388 \mathrm{bp}$ \\
\hline \multirow{2}{*}{ CA II } & F-GGG CCT TCA GAA AGT TGT TG & 29 and 33 cycles \\
\hline & R-GGG TCC AAA TCA CCA AGG TA & Product size $295 \mathrm{bp}$ \\
\hline \multirow{2}{*}{ CFTR } & F-ATT TTC CGG AGG ATG ATT CC & 29 and 33 cycles \\
\hline & R-CTG GGC TAG GGA GAA TGA TG & Product size $295 \mathrm{bp}$ \\
\hline \multirow{2}{*}{ CK 20} & F-CTC CAG TCC CAT CTC AGC AT & 29 and 33 cycles \\
\hline & R-TTC AGA TGA CAC GAC CTT GC & Product size 351 bp \\
\hline \multirow[t]{2}{*}{ Col I } & F-ACG TGA TCT GTG ACG AGA CC & 34 cycles \\
\hline & R-AGC AAA GTT TCC TCC GAG GC & Product size 265 bp \\
\hline \multirow[t]{2}{*}{ CTGF } & F-GTT CCA AGA CCT GTG GGA TG & 24 cycles \\
\hline & R-CAG TTG TAA TGG CAG GCA CA & Product size $361 \mathrm{bp}$ \\
\hline \multirow[t]{2}{*}{ Desmin } & F-TGG TTT CTG GGA AGT TGA GG & 33 cycles \\
\hline & R-CAT CGC GGC TAA GAA CAT TT & Product size 446 bp \\
\hline \multirow[t]{2}{*}{ Fibronectin } & F-TAT GCC GTT GGA GAT GAG TG & 24 cycles \\
\hline & R-CAG TAG TGC CTT CGG GAC TG & Product size 397 bp \\
\hline \multirow[t]{2}{*}{ GFAP } & F-GGG AGC TTG ATT CTC AGC AC & 35 cycles \\
\hline & R-TGC AGG AAT ATG AGC CAG TG & Product size $602 \mathrm{bp}$ \\
\hline \multirow[t]{2}{*}{ RPL13A } & F-CAT CGT GGC TAA ACA GGT ACT G & 22 cycles \\
\hline & R-GCA CGA CCT TGA GGG CAG CC & Product size $319 \mathrm{bp}$ \\
\hline \multirow[t]{2}{*}{ TGF $\beta 1$} & F-CAG AAA TAC AGC AAC AAT TCC TGG & 28 cycles \\
\hline & R-TTG CAG TGT GTT ATC CCT GCT GTC & Product size $190 \mathrm{bp}$ \\
\hline \multirow[t]{2}{*}{ Vimentin } & F-CAG GAC TCG GTG GAC TTC TC & 29 cycles \\
\hline & R-CGC ATT GTC AAC ATC CTG TC & Product size $399 \mathrm{bp}$ \\
\hline
\end{tabular}


Blot membranes were blocked in Tris-buffered saline (TBS, $10 \mathrm{mM}$ Tris, $10 \mathrm{mM} \mathrm{NaCl}$ ) containing $5 \%$ blocking solution (Amersham) and probed with the respective antibodies. The following antibodies were used: SV40 large T (Calbiochem), cytokeratin (CK) 19 (Sigma), FN (Sigma), Col I (Rockland) and $\alpha$ SMA (Sigma). Detection antibodies were from Dako (rabbit-anti-mouse-HRP and swine-anti-rabbit-HRP, 1:5000 for $1 \mathrm{~h}$ at room temperature) or from Pierce (goat-anti-mouse-HRP and goat-anti-rabbit-HRP, 1:5000 for $1 \mathrm{~h}$ at room temperature). ECL plus (Amersham) or SuperSignal West Femto Maximum Sensitivity Substrate (Pierce) was used for visualization.

Indirect immunocytochemistry was used as previously described. ${ }^{32}$ The primary antibodies used were directed against SV40 large T (Calbiochem, 1:100), CK 19 (Sigma, 1:200), CK 20 (Dako, 1:200), $\alpha$ SMA (Dako, 1:100), GFAP (Sigma, 1:200), desmin (Santa Cruz, 1:100), vimentin (Roche, 1:100) and carbonic anhydrase type II (CA II) (Pan Systems; 1:200). Secondary and tertiary antibodies used for immunocytochemical staining were HRP-conjugated rabbit-anti-mouse, rabbit-anti-goat and swineanti-rabbit IgGs (all from Dako, 1:100) using 3amino-9-ethylcarbazole (AEC) (Chemicon) as color substrate.

\section{Telomerase Activity}

The expression of the transfected telomerase was analyzed with the Telomerase PCR ELISA Kit (Roche) according to the manufacturer's recommendations, using Capan-1 cells and fibroblasts as positive and negative controls, respectively.

\section{Cell Cycle Analysis}

The effect of TGF $\beta 1$ on the cell cycle of RLT-PSC cells was analyzed on a FACScalibur flow cytometer (Becton Dickinson) as previously described. ${ }^{33}$ The cells were incubated with TGF $\beta 1(5 \mathrm{ng} / \mathrm{ml})$ in the presence of 5\% FCS or no FCS supplement for $24 \mathrm{~h}$. Subsequently, the cells were detached with trypsin/ EDTA, fixed with $70 \%$ ethanol for $1 \mathrm{~h}$ at $4^{\circ} \mathrm{C}$ and stained with Telford reagent (EDTA $90 \mu \mathrm{M}, 10 \mathrm{U} / \mathrm{ml}$ RNase A, $50 \mu \mathrm{g} / \mathrm{ml}$ propidium iodide and $0.1 \%$ Triton X-100 in PBS) for $45 \mathrm{~min}$ at $4^{\circ} \mathrm{C}$. Cell cycle analysis was performed with FlowJo software.

\section{Proliferation Assays}

Since TGF $\beta 1$ is known to induce a growth arrest in human PSC, TGF $\beta 1$ stimulation experiments were performed in the presence of $5 \%$ FCS in order to have an adequate proliferative capacity of the cells. They were seeded onto a 96-well culture dish (5000 cells/well) and subsequently, the cells were treated with TGF $\beta 1(0,1,5,10 \mathrm{ng} / \mathrm{ml})$ in DMEM with $5 \%$
FCS for 6 days. For proliferation assays using the PSC mitogen PDGF, the cells were serum-starved overnight and subsequently stimulated with PDGFB $(0,5,10,20 \mathrm{ng} / \mathrm{ml})$ in serum-free DMEM for 6 days. Proliferation was analyzed with the watersoluble tetrazolium salt WST-1 (4-[3-(4-iodophenyl)2-(4-nitrophenyl)-2H-5-tetrazolio]-1,3-benzene disulfonate) (Roche) according to the manufacturer's instructions, using an ELISA reader $2 \mathrm{~h}$ after WST-1 addition.

\section{Response to TGF $\beta 1$ Stimulation}

To examine whether RLT-PSC responds adequately to stimuli implicated in the activation of PSC, the cells were stimulated in the absence of FCS with TGF $\beta 1(5 \mathrm{ng} / \mathrm{ml})$ for $4 \mathrm{~h}$ after overnight serum starvation. ${ }^{15,17}$ After TGF $\beta 1$ treatment, RNA isolation and RT-PCR or Western blot analysis was performed as described above.

\section{Oil Red Staining and Vitamin A Autofluorescence}

For the staining of fat storing vesicles, the cells were fixed with $4 \%$ buffered formalin for $10 \mathrm{~min}$ at room temperature. ${ }^{19}$ Subsequently, the cells were washed with PBS (two times, one minute each) and covered with a saturated solution of oil red in acetone: ethanol (1:9) for $10 \mathrm{~min}$ at room temperature. After extensive washing with distilled water, the cells were examined by light microscopy. Vitamin A storing in the lipid vesicles was demonstrated by fluorescence microscopy using an excitation wavelength of $320-380 \mathrm{~nm}$ to visualize the characteristic rapidly fading blue-green fluorescence of vitamin A.

\section{Effect of Matrigel and $\boldsymbol{N}$-Acetylcysteine on PSC}

Cultivation on Matrigel and treatment with $\mathrm{N}$ acetylcysteine (NAC) has been reported to induce a quiescent state with a decrease in matrix production in activated HSC. ${ }^{34-36}$ To analyze if the same may be true for PSC, the immortalized cells and cultureactivated human PSC were cultured in DMEM plus $5 \%$ FCS in either the presence or the absence of $2.5 \mathrm{mM}$ NAC on a layer of Matrigel for up to 10 days. The Matrigel layer was prepared by adding $600 \mu \mathrm{l}$ of diluted Matrigel (1:2 in serum-free culture medium) to the wells of a six-well culture plate. The gel was allowed to solidify at $37^{\circ} \mathrm{C}$ for $24 \mathrm{~h}$ before seeding of the cells. The cells were then used for oil red staining and for gene expression analysis by RTPCR, as described above. RNA for gene expression analysis was prepared according to the protocol provided by the manufacturer of the RNeasy mini Kit (Qiagen) by adding buffer RLT plus $\beta$-ME (350 $\mu \mathrm{l}$ for cells on pure TC plates, $950 \mu \mathrm{l}$ for cells grown on Matrigel) directly to the cultured cells. In order to analyze the effects of Matrigel and NAC on the 
proliferation of PSC, the cells were seeded in DMEM plus $5 \%$ FCS, $\pm 2.5 \mathrm{mM}$ NAC on either Matrigelcoated or plain 96-well plates (5000 cells/well). After 5 days of incubation, the proliferation was analyzed by the WST-1 assay, as described above.

\section{Statistical Analysis}

Results are expressed as mean \pm standard deviation (s.d.). Results were analyzed using the Student's $t$-test, $P<0.05$ was considered to be statistically significant.

\section{Results}

\section{Expression of Transfected cDNAs}

The expression of SV40 large $\mathrm{T}$ antigen was analyzed by Western blot and immunocytochemistry. Western blot experiments showed a protein of the expected size $(90 \mathrm{kDa})$, which, using indirect immunocytochemistry, was located solely in the nucleus of the transfected cells (Figure 1, left). Control cells (carcinoma cells and fibroblasts) did not express large $\mathrm{T}$ antigen. In TRAP-assays, the telomerase expression of the transfected cells was comparable to that of the positive control cells Capan-1 (RLT-PSC, $\mathrm{OD}_{450 \mathrm{~nm}}-\mathrm{OD}_{690 \mathrm{~nm}}$ : 1.090; Capan1 , $\mathrm{OD}_{450 \mathrm{~nm}}-\mathrm{OD}_{690 \mathrm{~nm}}: 1.501$ ), whereas in fibroblasts serving as negative controls no telomerase activity was detectable (fibroblasts; $\mathrm{OD}_{450 \mathrm{~nm}}-\mathrm{OD}_{690 \mathrm{~nm}}$ : 0.089). SV40 large $T$ is known to induce karyotype alterations in transfected cells. In RLT-PSC cells, the mean chromosome number was increased to 60 chromosomes (Figure 1, middle). Using a soft agar cloning assay, we next analyzed if the expression of the transfected cDNAs resulted in a transformed phenotype of the RLT-PSC cells. Only a very small percentage of the cells $(0.65 \%, \pm 0.13$; mean \pm s.d. of three determinations) were able to grow anchorageindependently and to form colonies in soft agar (Figure 1, right).

\section{Expression of Marker Proteins}

RT-PCR revealed expression of the stellate cell and activation markers GFAP, desmin, vimentin and $\alpha S M A$ (Figure 2a) in the immortalized PSC. Desmin, vimentin and $\alpha S M A$ were also expressed by fibroblasts. The unexpected finding of $\alpha S M A$ expression in fibroblasts was due to a small percentage of $\alpha \mathrm{SMA}$ positive cells in our fibroblast preparation. On the other hand, almost all the immortalized cells exhibited strong $\alpha \mathrm{SMA}$ staining. GFAP was expressed exclusively in the immortalized cells and thus was the only marker to discriminate the immortalized PSC from the fibroblasts (Figure 2a). Immunocytochemistry demonstrated a marked expression of the proteins $\alpha \mathrm{SMA}$, vimentin and GFAP, which were organized in fibrillary structures. In contrast, desmin was only detectable as a very faint staining throughout the cytoplasm of the immortal cells (Figure 2b). Using the same two methods, no expression of the epithelial markers CK19, CK20, CA II and cystic fibrosis transmembrane conductance regulator (CFTR) was detectable in RLT-PSC cells (data not shown).
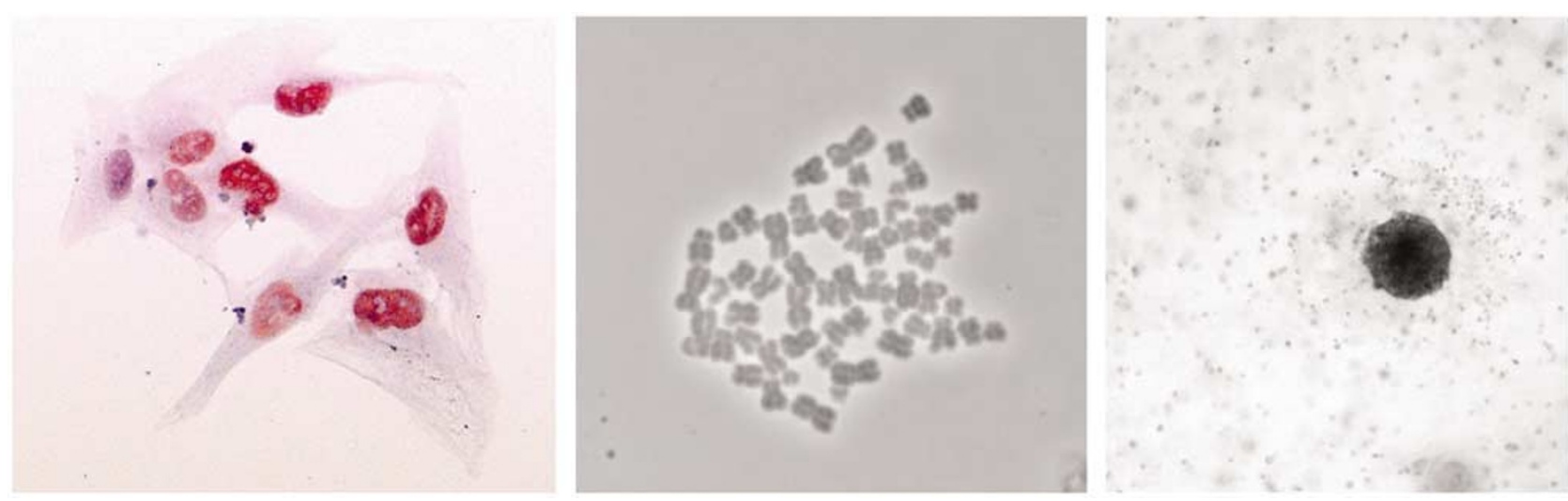

Figure 1 Immunocytochemistry of RLT-PSC cells using an antibody against SV40 largeT antigen showing the expected intense nuclear staining (left). Karyotype analysis of RLT-PSC cells revealed a mean number of 60 chromosomes (middle). Soft agar cloning assays demonstrated that only a very small percentage of the cells $(0.65 \%, \pm 0.13$; mean \pm s.d. of three determinations) was able to grow anchorage-independently and to form colonies in soft agar (right).

Figure 2 Expression of stellate cells marker proteins in RLT-PSC demonstrated by RT-PCR (a) and immunocytochemistry (b). On the RNA-level GFAP expression was the only marker to discriminate RLT-PSC from fibroblasts (a). M: 100 bp marker, n.c.: neg. control, S: RLT-PSC, C: Capan-1, F: fibroblasts. Protein expression of $\alpha$-smooth muscle actin ( $\alpha$ SMA), glial fibrillary acidic protein (GFAP) and vimentin was detectable in nearly $100 \%$ of the cells. The proteins showed the typical fibrillary structures (b). In contrast desmin was detectable only as a faint staining throughout the cytoplasm of the cells (b). 
a

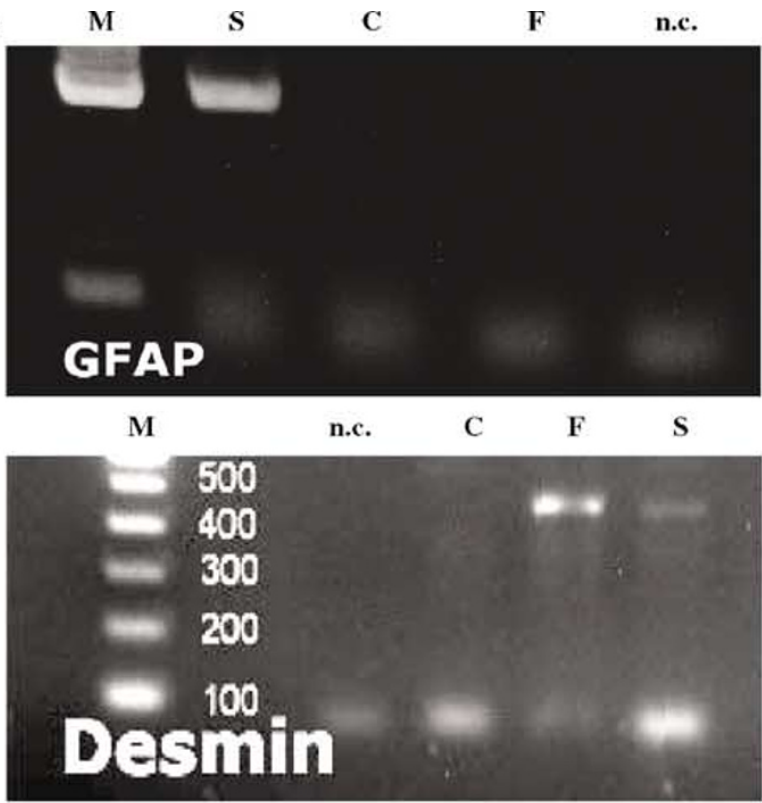

b

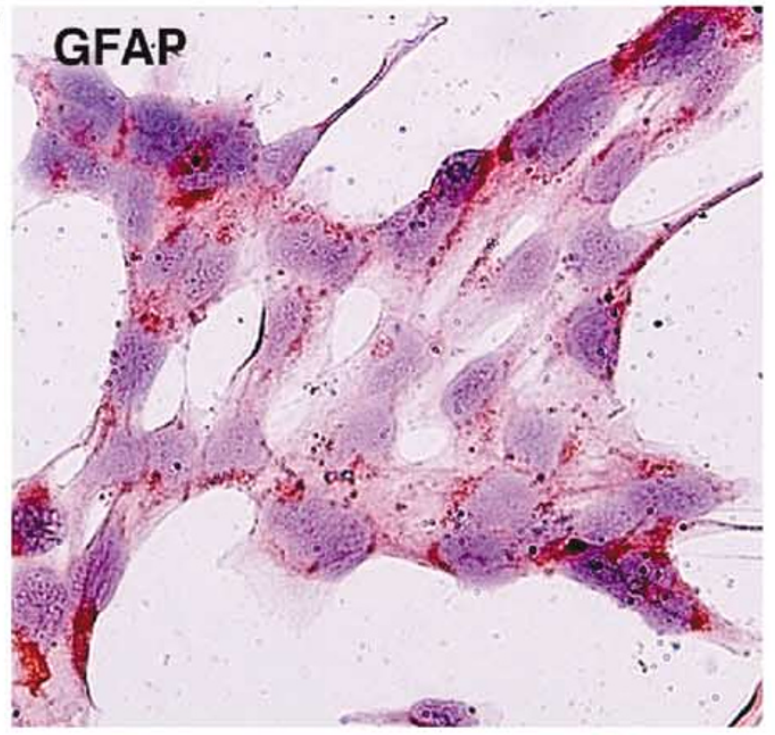

Desmin
M

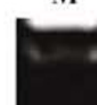

\section{$\alpha$ SMA}

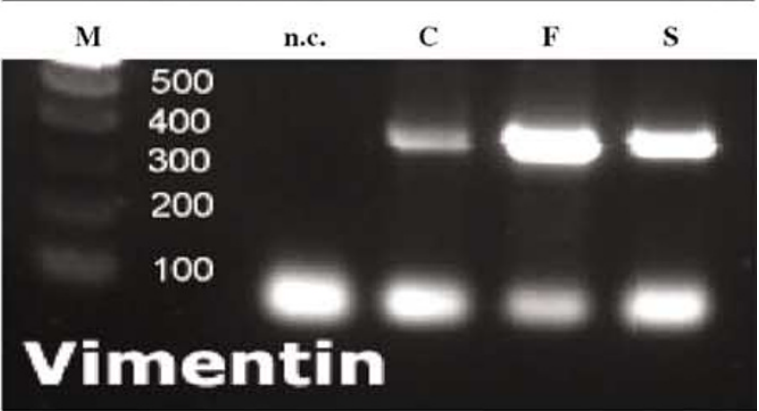

\section{aSMA}
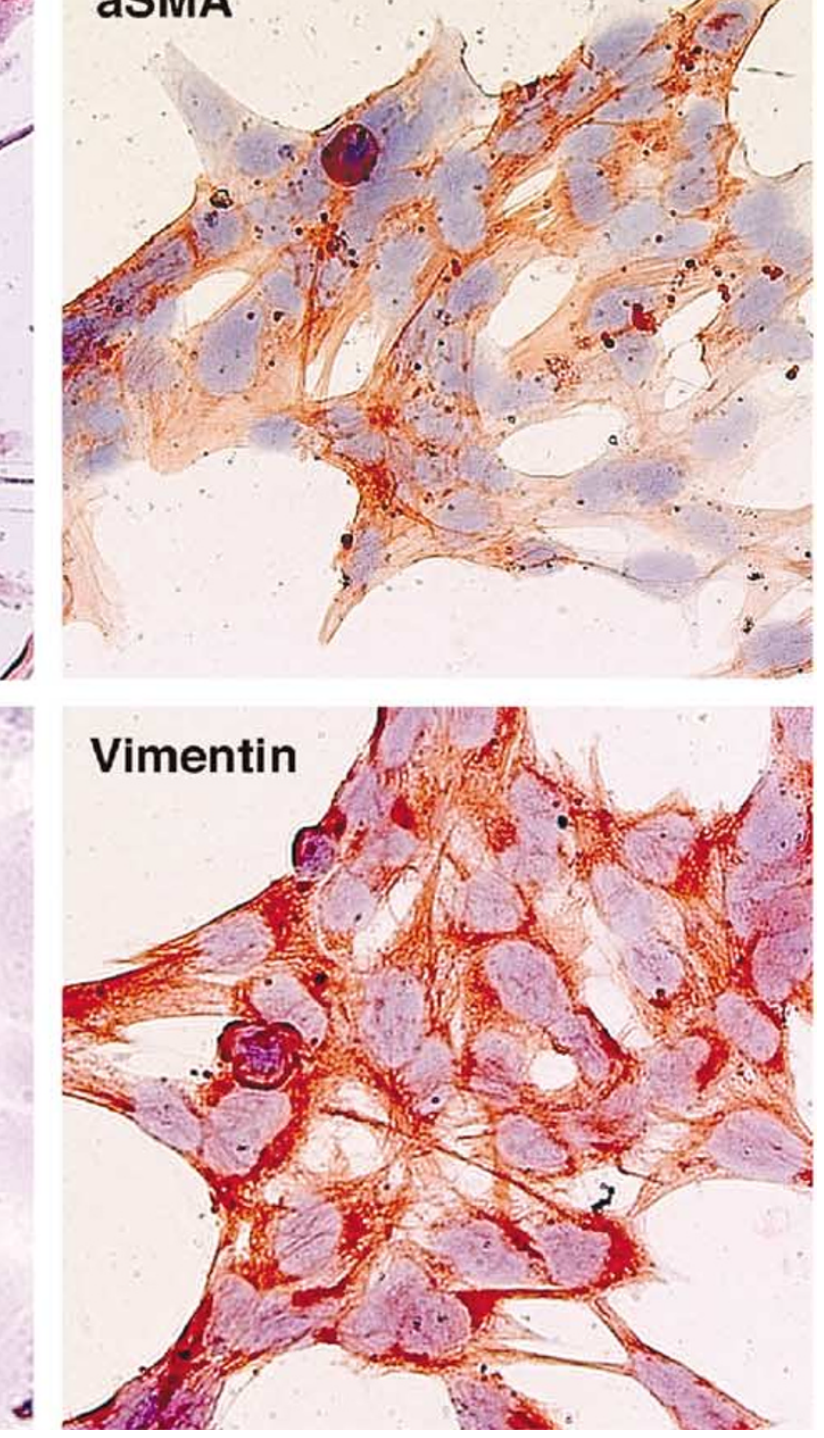

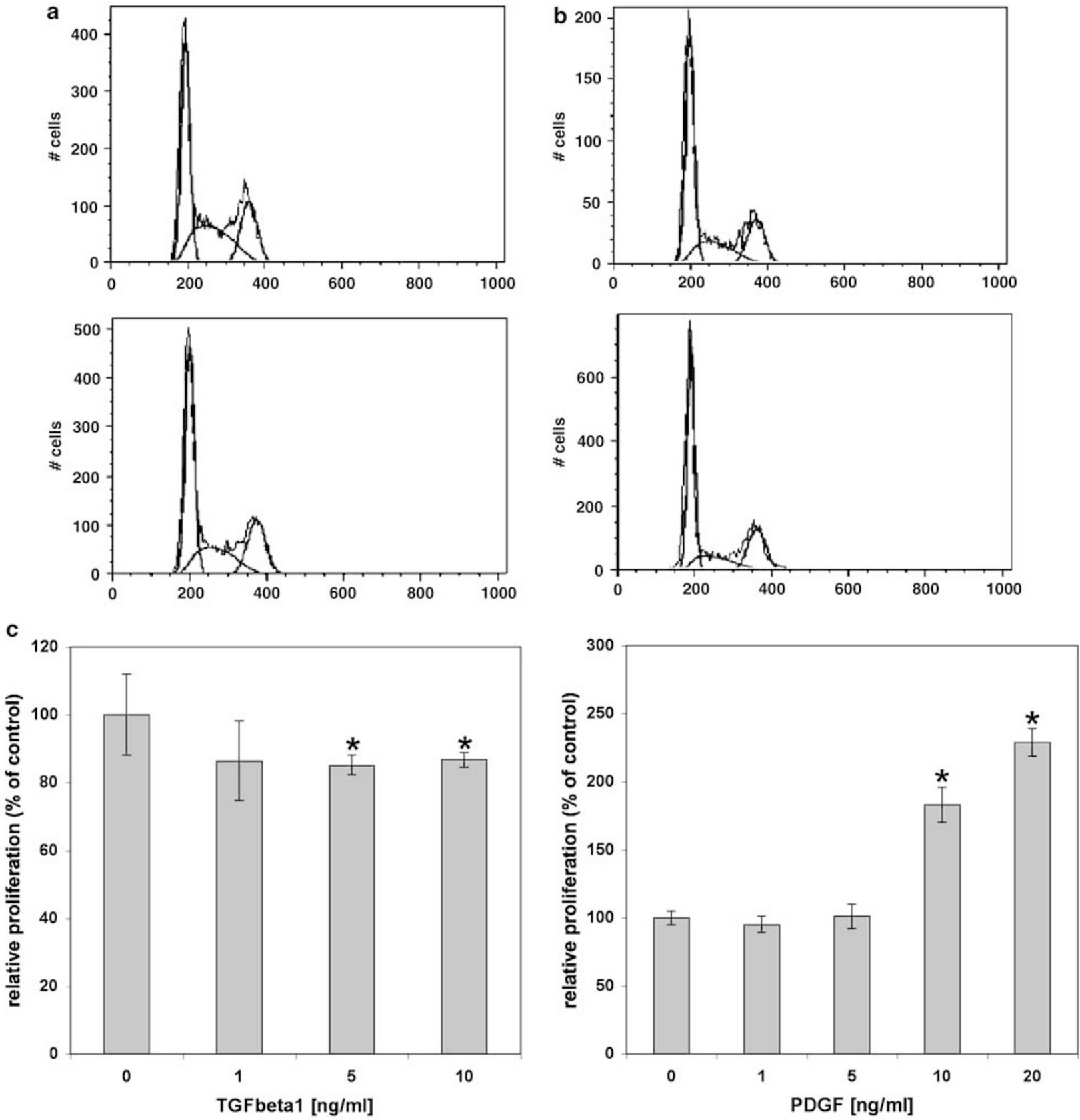

Figure 3 Effect of TGF $\beta 1$ on the cell cycle distribution of RLT-PSC. RLT-PSC cells were cultured in medium containing 5 \% FCS (a) or no FCS (b) without (upper panel) and with (lower panel) treatment with TGF $\beta 1$ ( $5 \mathrm{ng} / \mathrm{ml}$ for $24 \mathrm{~h}$ ). The cells showed a marked increase (from 43.4 to $55 \%$ ) of G1-phase cells induced by serum deprivation (a and $\mathbf{b}$, upper panels). Also TGF $\beta 1$ stimulation resulted in an increase of G1-phase cells (a and $\mathbf{b}$, lower panels), which was more pronounced in the presence of FCS (increase from 43.4 to $50.4 \%$ in medium plus FCS versus an increase from 55 to $56.1 \%$ in medium without FCS) (a, lower panel). Effect of TGF $\beta 1$ and PDGF-B on the proliferation of immortalized PSC (c). The cells were treated either with TGF $\beta 1(0,1,5,10 \mathrm{ng} / \mathrm{ml})$ in $5 \%$ DMEM or with PDGF-B $(0,5,10,20 \mathrm{ng} / \mathrm{ml})$ after overnight serum starvation in serum-free DMEM for 6 days. Proliferation was analyzed with the water-soluble tetrazolium salt WST-1. TGF $\beta 1$ resulted in a moderate growth inhibition reaching statistical significance at 5 and $10 \mathrm{ng}$ TGF $\beta 1$ per ml (c, left panel). In contrast, PDGF, a known mitogen for PSC, significantly increased the proliferation of the immortalized PSC at concentrations of 10 and 20 ng PDGF-B per ml (c, right panel). Data are mean \pm s.d. of two experiments, *denotes $P<0.01$ compared to controls.

\section{Cell Cycle Analysis}

Treatment of RLT-PSC with $5 \mathrm{ng} / \mathrm{ml}$ TGF $\beta 1$ for $24 \mathrm{~h}$ in the presence of $5 \%$ FCS resulted in an increase of the G1-phase population ( 43.4 vs $50.4 \%$ ) of the cells. In addition, the $S$-phase population decreased from
34.2 to $26.1 \%$ whereas the G2-phase population was only changed marginally (Figure 3a). Serum deprivation of the cells resulted in an even more pronounced increase of G1-phase cells from 43.4 to $55 \%$ (Figure 3a and b, upper panels). Treatment with TGF $\beta 1$ resulted in a slight further increase in 
G1-phase cells, whereas the number of S-phase cells was markedly diminished (Figure $3 b$ ).

\section{Proliferation Assays}

TGF $\beta 1$ treatment induced a maximal growth inhibition of $15 \%$ of RLT-PSC cells cultured with $5 \%$ FCS with all TGF $\beta 1$ concentrations used, reaching statistical significance for 5 and $10 \mathrm{ng} / \mathrm{ml}$ of TGF $\beta 1$ (Figure 3c, left panel).

In contrast, stimulation with PDGF, a wellknown mitogen for PSC, dose dependently increased the proliferation of RLT-PSC cells up to $229 \%$ of controls with a maximum effect at a PDGF concentration of $20 \mathrm{ng} / \mathrm{ml}$ (Figure 3c, right panel).

\section{Response to TGF $\beta 1$ Treatment}

In order to ascertain that the immortalization process did not result in an alteration of the phenotype of RLT-PSC cells, the effect of TGF $\beta 1$ on the expression of genes and proteins, known to be induced by TGF $\beta 1$ in activated PSC, was investigated in our immortalized clone using conventional RT-PCR, real-time RT-PCR and Western blot. The ribosomal gene RPL13A was used as housekeeping gene for the gene expression experiments. ${ }^{31}$ TGF $\beta 1$ induced a marked upregulation of the ECM proteins $\mathrm{Col} I$ and $F N$ on the RNA level (Figure 4a and b). Using real-time RT-PCR, we were able to verify the TGF $\beta 1$ induced Col I expression on the RNA level (Figure 4b). Using dot blot and Western blot analysis of conditioned media and whole-cell lysates, we were able to confirm the upregulation of Col I and FN also on the protein level (Figure 5a). Expression of $\alpha$ SMA, a marker for PSC activation, was induced as well on the RNA level (Figure 4a and b) as on the protein level (Figure 5b), after treatment of the immortalized PSC with TGF $\beta 1$. Conventional RTPCR (Figure 4a) or quantitative real-time RT-PCR (Figure 4b) revealed an upregulation of the growth factors TGF $\beta 1$ and connective tissue growth factor $(C T G F)$, both implicated in the development of pancreatic fibrosis, after stimulation with TGF $\beta 1$.

\section{Effects of Matrigel Cultivation and NAC Treatment}

Cultivation of the immortalized and primary human PSC on a layer of Matrigel resulted in an alteration of the morphology of the cells. They lost their flattened myofibroblast-like appearance and formed cell clusters, which were connected by a filamentous network (Figure 6a). Importantly, during the cultivation on Matrigel, the immortalized and the cultureactivated native PSC regained the ability to store vitamin A in cytoplasmic vesicles, a feature of not-activated native PSC, as evidenced by oil red staining and vitamin A fluorescence (Figure 6b). These morphological changes were accompanied by drastic changes of gene expression. Thus cultivation of the immortalized PSC on Matrigel for 7 days resulted in a marked decrease of Col I, TGF $\beta 1$ and CTGF expression compared to cultivation on tissue culture plates, reminiscent of the expression pattern in not-activated PSC, whereas $\alpha S M A$ expression was not altered significantly by these cultivation conditions (Figure 7a). RT-PCR also demonstrated that cultivation of culture-activated native human PSC on Matrigel induced a marked downregulation of the activation markers $\alpha S M A$ and $C T G F$, while upregulating GFAP expression, whereas Col I and WAF1 expression were not altered. Concomitant treatment of Matrigel cultured cells with NAC $(2.5 \mathrm{mM})$ augmented $\alpha S M A$ and CTGF downregulation, while it attenuated the upregulation of GFAP expression (Figure 7b). Moreover, this treatment downregulated Col I expression, also leaving WAF1 expression unchanged. Treatment of primary human PSC grown on plain TC plates with NAC also induced a decrease of $\alpha S M A$, but to a lesser extent than did Matrigel cultivation. NAC reduced CTGF expression to similar levels as Matrigel cultivation, but had no effect on GFAP and WAF1 expression. However, in contrast to Matrigel cultivation, NAC treatment was able to decrease Col I expression (Figure 7b).

Treatment of primary human PSC cultured on tissue culture plates with NAC resulted in a modest but significant decrease of the proliferation of the cells ( $13 \%$ growth inhibition, $P<0.01)$, and this effect was significantly enhanced when the cells were grown on Matrigel (27\% growth inhibition, $P<0.01)$. Cultivation of the cells on Matrigel alone, without NAC treatment, had no effect on the proliferation of the cells (Figure 7c).

\section{Discussion}

Activated PSC play a central role in the development of fibrotic tissue in chronic pancreatitis as well as in pancreatic cancer. Owing to the finite lifespan of normal PSC, the mechanism underlying this activation process had to be analyzed on primary culture, putting up with the drawbacks of this method, such as time-consuming isolation of the cells and variations between different preparations. Recently, the immortalization of rat PSC has been reported, pointing out the need of appropriate in vitro models. ${ }^{20-22}$ However, an immortalized human PSC line has not been available up to now. We established an immortal human PSC line, named RLT-PSC, from human pancreas, by transfection with the SV40 large $\mathrm{T}$ antigen and the catalytic subunit of the hTERT, which will help to overcome this obstacle. As we initially intended to immortalize human pancreatic epithelial cells, we used a supplemented keratinocyte growth medium for the cells to be transfected. Although this medium is not optimal to support the growth of PSC, we obtained 

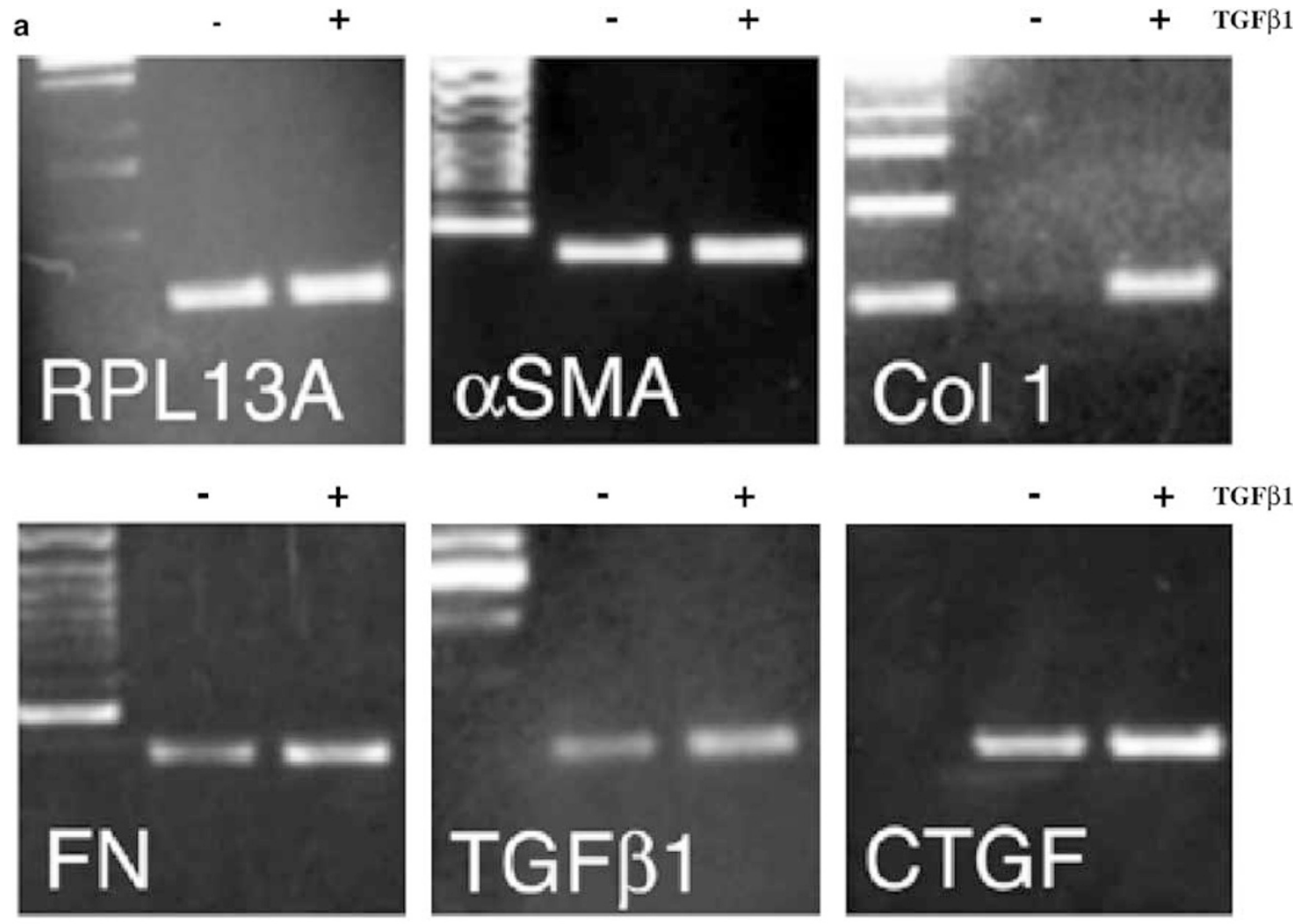

b

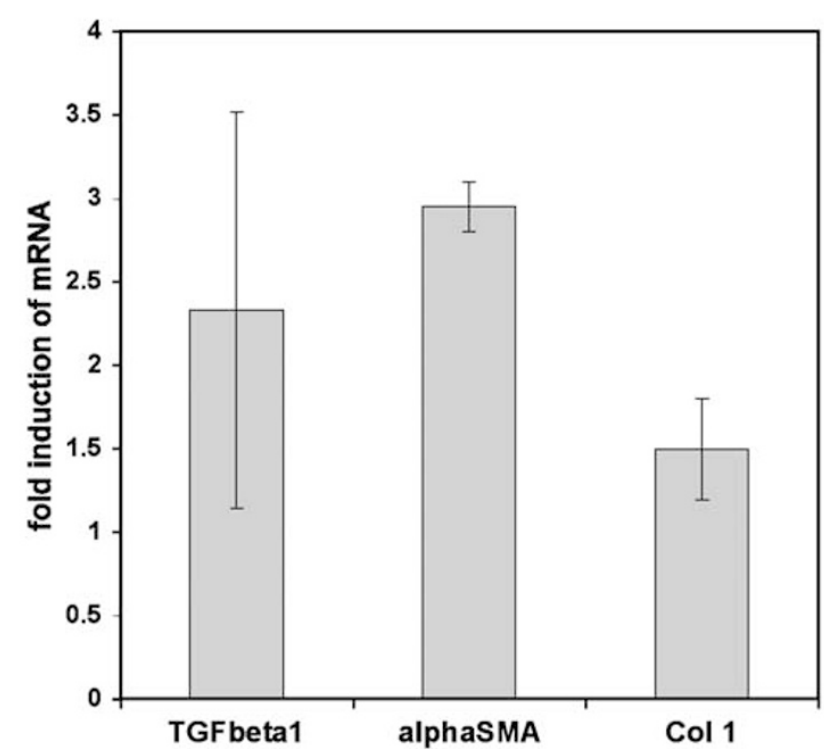

Figure 4 Effect of TGF $\beta 1$ on the expression of selected genes. The cells were stimulated in the absence of FCS with TGF $\beta 1$ ( 5 ng/ml) for $4 \mathrm{~h}$ after overnight serum starvation. Subsequently, gene expression was analyzed by RT-PCR. TGF $\beta 1$ induced an increase of gene expression in all genes investigated, namely the activation marker $\alpha S M A$, the ECM proteins Col I and FN as well as the growth factors TGF 1 and CTGF. The housekeeping gene RPL13A served as control (a). The observed expression pattern was verified for three genes (TGF $\beta 1, \alpha S M A$ and $C o l I$ ) using real-time RT-PCR (b).

several resistant mesenchymal cell clones, of which RLT-PSC became immortal. The expression of the transfected genes was verified by Western blot analysis, immunocytochemistry and TRAP-ELISA, respectively. Since RLT-PSC passed terminal crisis and has been passaged more than 20 times there- after, it can be assumed to be immortal. ${ }^{37}$ Expression of large $\mathrm{T}$ antigen may result in a transformed phenotype indicated by the independence from growth factors. ${ }^{38}$ This phenomenon was recently shown in immortalized human HSC. ${ }^{39}$ However, in our RLT-PSC cells, serum deprivation resulted in a 


\section{a}
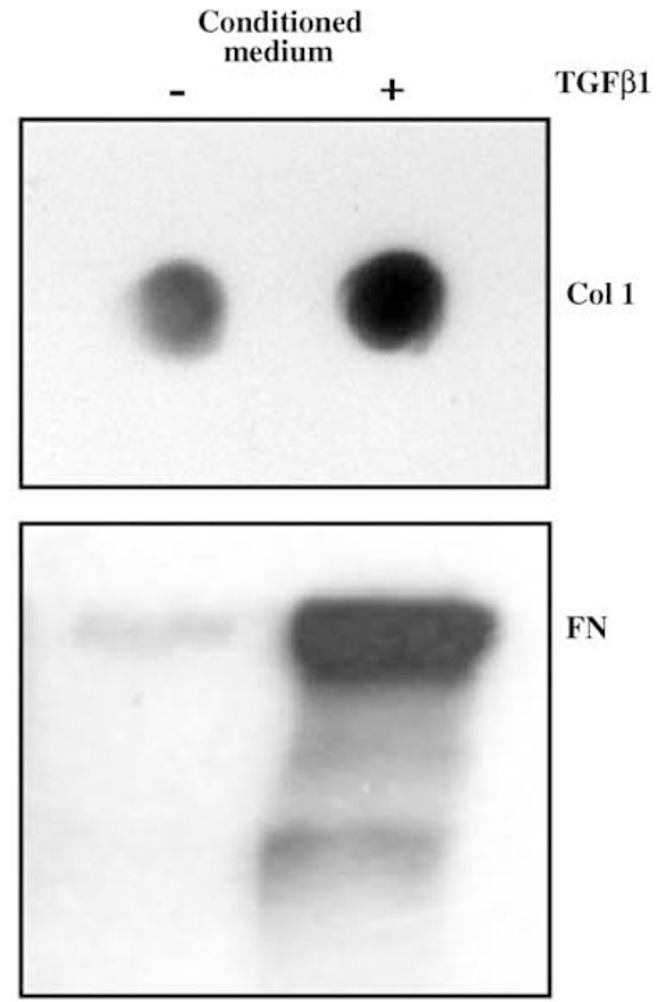

b

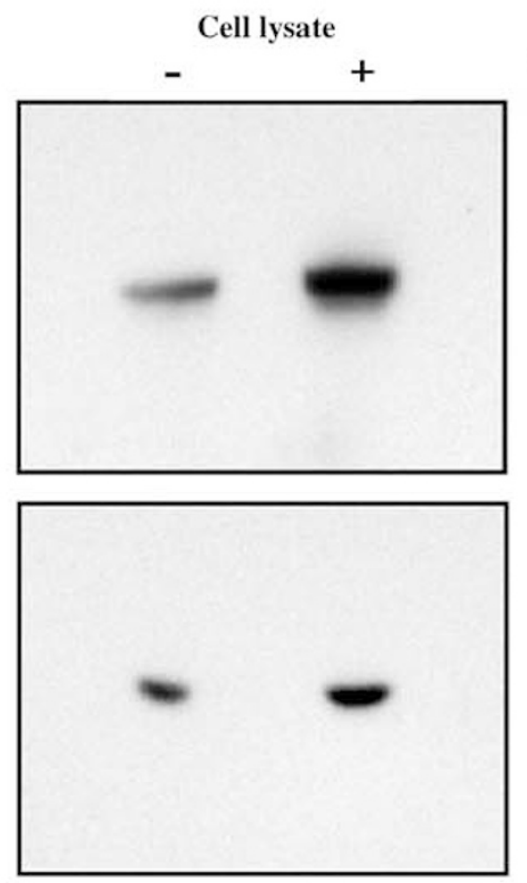

$\alpha$ SMA

Col 1

(1)

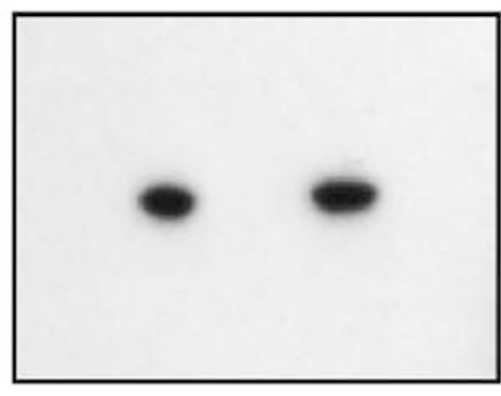

G1-arrest of the cells, showing the dependence on serum factors as an indicator for a normal, that is, not malignantly transformed, phenotype. Nevertheless, the expression of the transfected large T antigen induced considerable alterations of the karyotype and the mean chromosome number was increased to 60 chromosomes, an effect already described in a variety of SV40 large T immortalized cells. ${ }^{24,40-43}$ As these alterations might have induced a transformation of the cells, a soft agar cloning assay was performed to check for the ability of the cells to grow anchorage independently. Only a very small percentage $(0.65 \%)$ of the cells was able to form colonies in soft agar. Thus, the vast majority of RLT-PSC cells resemble a normal phenotype, despite the alterations in their karyotype.

RLT-PSC was established from tissue obtained from a chronic pancreatic tissue resection; thus, the PSC were already activated, ie in a proliferative state, apparently a prerequisite for the isolation of the cells by the outgrowth method. ${ }^{9,15}$ The immortalized PSC was retained to express markers of activated PSC, namely $\alpha$ SMA, vimentin, desmin and GFAP, even after prolonged passaging of the cells. $^{8,9}$ GFAP expression also has been used by others to identify pancreatic/HSC and to discriminate them from myofibroblasts. ${ }^{8,44}$ Vimentin, $\alpha$ SMA and GFAP were expressed in well-organized fibrillary structures, a feature found in culture-activated PSC. ${ }^{20,21}$

Besides the expression of PSC marker proteins, responsiveness to factors implicated in the pathogenesis of pancreatic fibrosis has to be retained in the immortalized cells. For this reason, we analyzed the effect of TGF $\beta 1$ and PDGF on our cell line. Treatment of the cells with TGF $\beta 1$ resulted in an increase of G1-phase cells and a simultaneous decrease of S-phase cells, classical features of a G1-arrest induced by TGF $\beta 1$, found in a variety of cells. $^{45,46}$ This G1-arrest was induced in RLT-PSC cells cultured with or without serum but was more pronounced in cells cultured in medium containing FCS, presumably due to the arrest already induced by serum deprivation.

Treatment of RLT-PSC with TGF $\beta 1(1-10 \mathrm{ng} / \mathrm{ml})$ resulted in a decrease of proliferation. Similar findings were observed in PSC, whereas others did

Figure 5 Effect of TGF $\beta 1$ on the expression of selected proteins. In order to analyze the secretion of collagen I and FN induced by TGF $\beta 1$ challenge, the cells were incubated in equal volumes of serum-free culture medium with or without addition of TGF $\beta 1$ for $24 \mathrm{~h}$. Subsequently, the conditioned media were harvested and volumes corrected for the number of cells were analyzed by Western blot (FN) or dot blot (Col I). TGF $\beta 1$ markedly induced secretion of both FN and Col I into the culture medium (a). Whole-cell lysates were prepared by incubating the cells with denaturing Laemmli buffer. TGF $\beta 1$ challenge markedly increased Col I, whereas it only marginally induced $\alpha$ SMA expression in the immortalized on the protein level. The constitutively expressed transgene SV40 large T antigen was used as a loading control (b). 
not find such an effect of TGF $\beta 1$ on the growth of PSC. ${ }^{15,47,48}$ The same is true for HSC, where contrasting data describing the influence of TGF $\beta 1$ on proliferation, ranging from growth inhibition to stimulation of proliferation, have been published, although the majority of publications report a TGF $\beta 1$-induced growth inhibition in HSC. ${ }^{44,49-51}$ These differences may be attributed to different
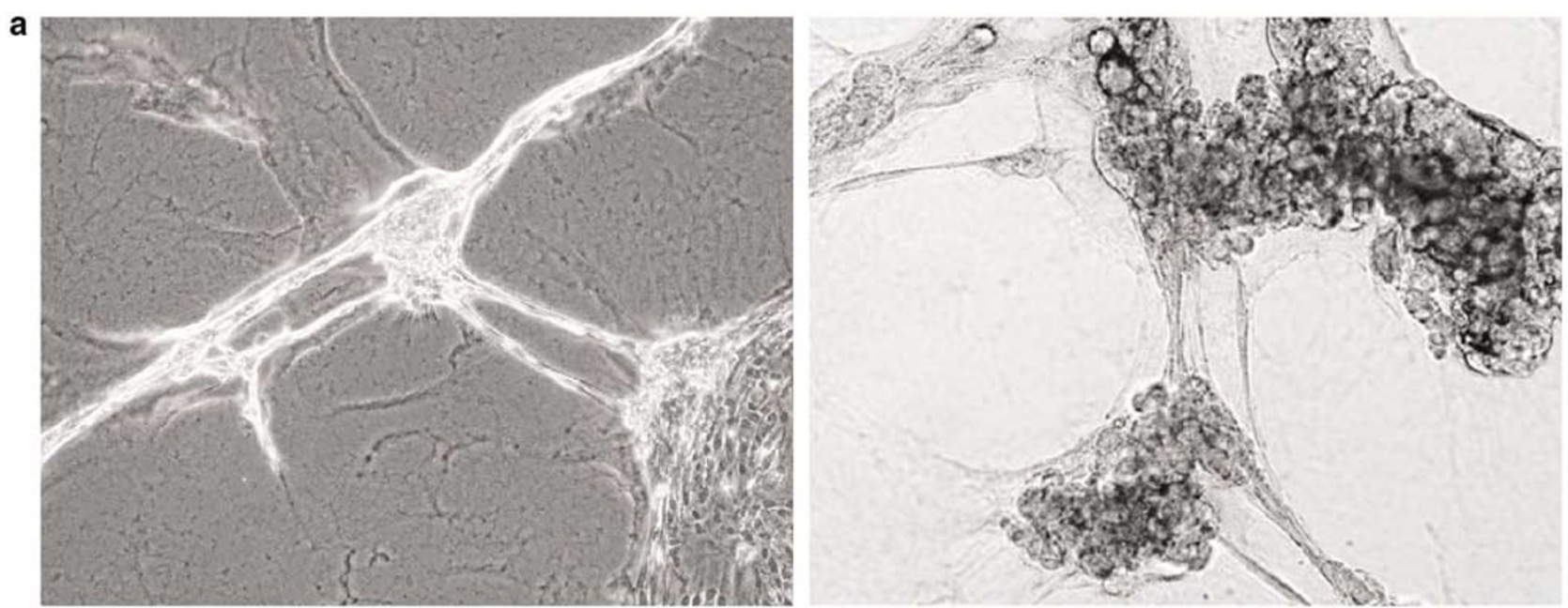

b
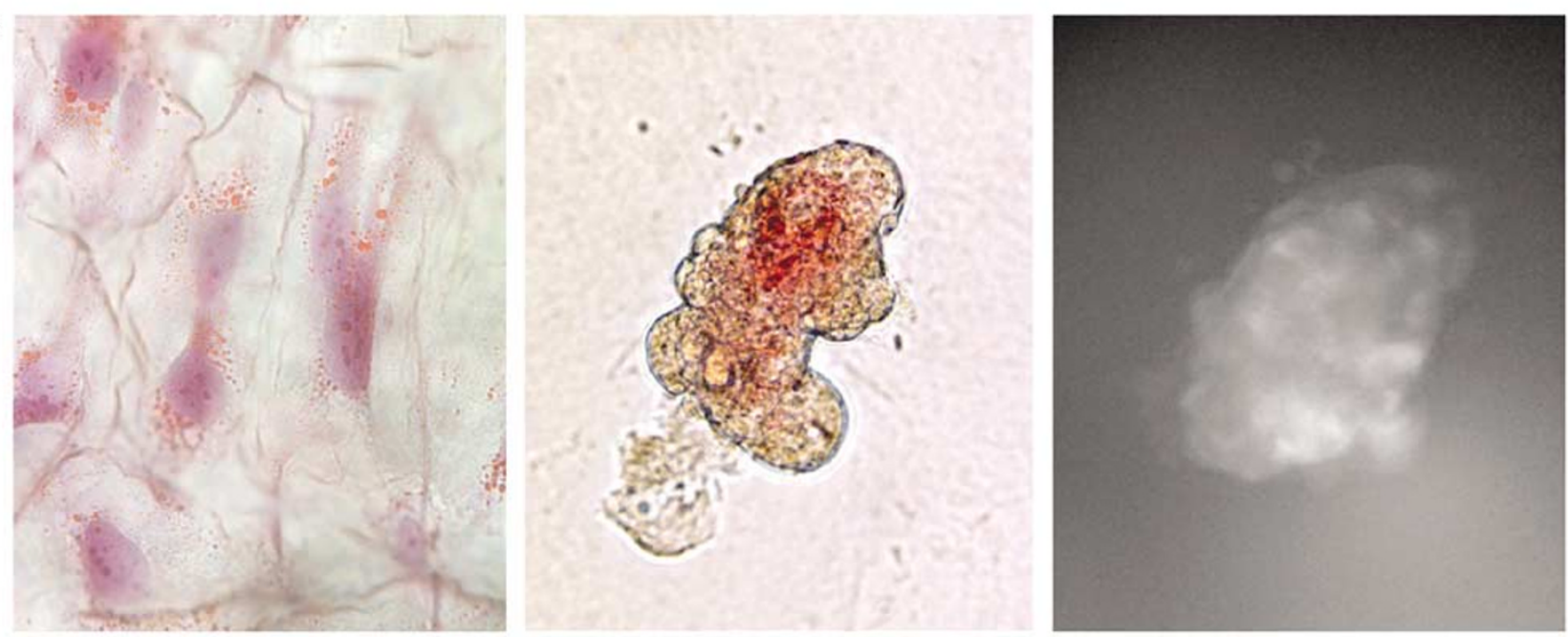

Figure 6 Effect of Matrigel cultivation on morphology and vitamin A storage of human PSC. Phase contrast microscopy of immortalized PSC (left, $\times 100)$ and bright field microscopy of primary human PSC (right, $\times 200$ ) seeded on a layer of Matrigel. The cells formed threedimensional cell clusters connected by a filamentous network (a). Immortalized (left, $400 \times$ ) and primary human PSC (middle, $\times 400$ ) cultured on Matrigel for 5-7 days regained the ability to store lipids in cytoplasmatic vesicles as shown by oil red staining. Using fluorescence microscopy, vitamin A was detectable in this vesicles by its autofluorescence at an excitation wavelength of $320-380 \mathrm{~nm}$ (right, $\times 400)(b)$, in cells cultured on normal tissue culture plates no lipid droplets were detectable.

Figure 7 Effect of Matrigel cultivation on gene expression and Proliferation of human PSC. RT-PCR demonstrated that cultivation of immortalized PSC on Matrigel (M) for 7 days resulted in a marked decrease of Col I, TGF $\beta 1$ and CTGF expression compared to cultivation on tissue culture (TC) plates, whereas $\alpha S M A$ expression was not altered significantly by this cultivation conditions, the housekeeping gene RPL13A served as control (a). Cultivation of primary human PSC on Matrigel induced a marked downregulation of $\alpha S M A$ and CTGF expression, while upregulating GFAP expression, whereas Col I and WAF1 expression was not altered by this cultivation. Simultaneous treatment with $N$-Acetylcysteine (NAC, $2.5 \mathrm{mM}$ ) augmented the $\alpha S M A$ and $C T G F$ downregulation, while attenuating the upregulation of GFAP expression, moreover this treatment downregulted Col I expression, also leaving WAF1 expression unchanged. Treatment of primary human PSC grown on plain TC plates with NAC had no effect on GFAP and WAF1 expression, in contrast it induced a decrease of $\alpha S M A$, Col I and CTGF expression (b). Treatment of primary human PSC with NAC resulted in a modest but significant decrease of the proliferation of the cells, and this effect was significantly enhanced, when the cells were grown on Matrigel. Cultivation of the cells on Matrigel alone without NAC treatment had no effect on the proliferation of the cells (c). Data are mean \pm s.d. of two independent experiments using primary PSC isolated from two patients, ${ }^{*}$ denotes $P<0.01$ compared to TC, ${ }^{* *}$ denotes $P<0.01$ compared to $\mathrm{TC}+\mathrm{NAC}$. 

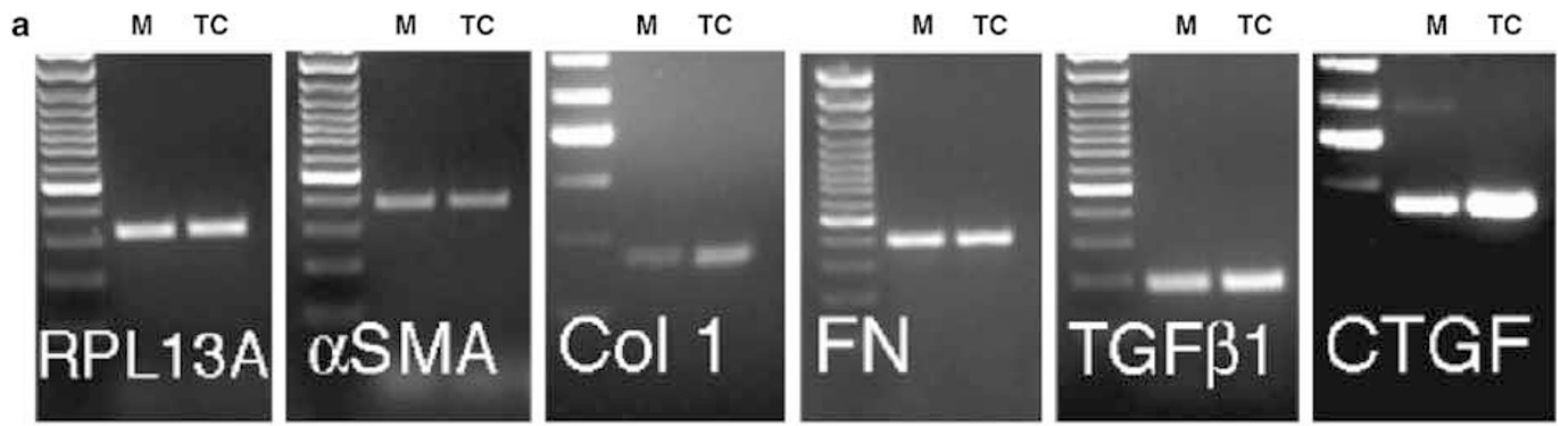

b
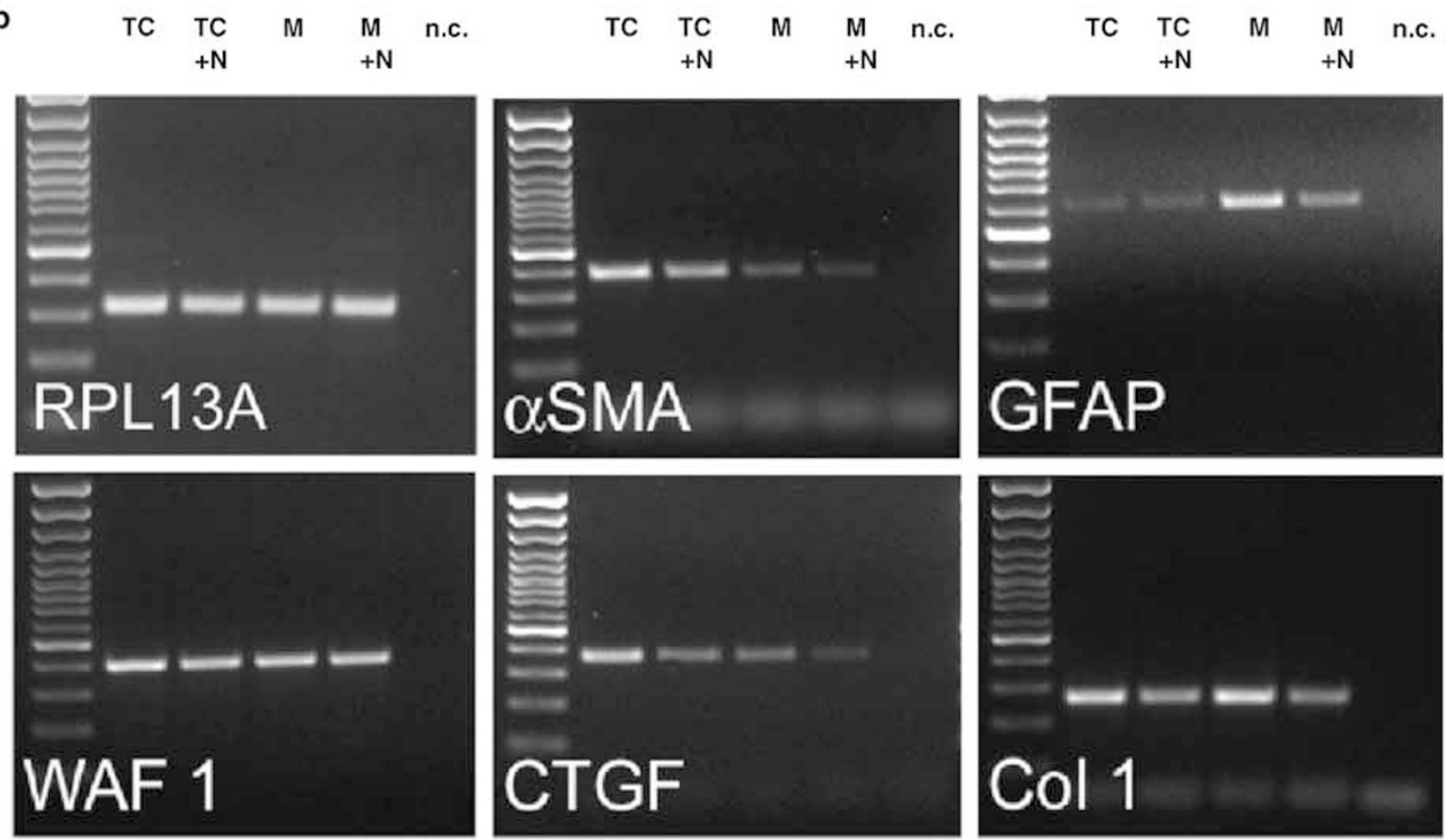

c

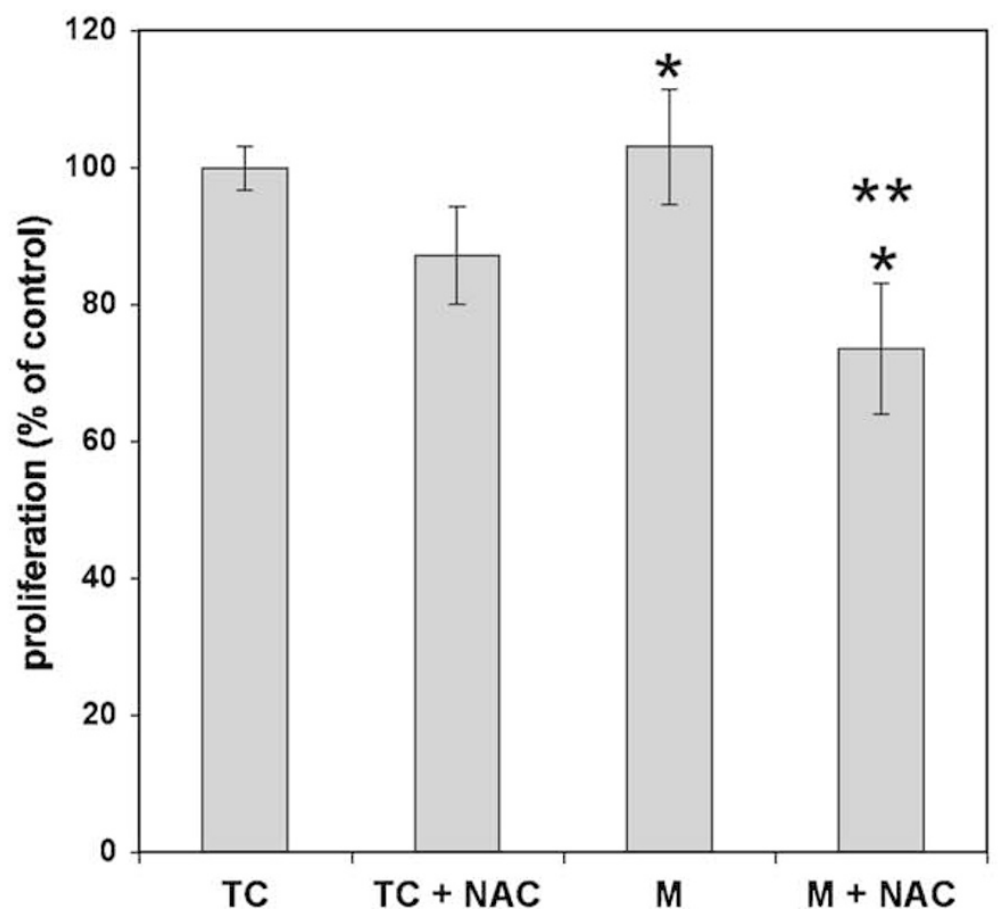


isolation techniques, which eventually select for different subpopulations of cells, or to the use of different activation phases or passages of the stellate cells. In contrast, treatment of the immortalized PSC with the PDGF, a growth factor known to increase the proliferation of primary stellate cells, also resulted in a concentration-dependent increase of proliferation in our immortalized PSC clone. ${ }^{11,15,17}$

The gene expression profile in response to TGF $\beta 1$ of RLT-PSC resembles the phenotype of activated PSC. The basal expression of $\alpha S M A$, Col $I$ and $F N$ is further induced by TGF $\beta 1$ both on the RNA and protein level, a feature commonly found in PSC. ${ }^{11,15}$ Since most of the Col I is incorporated in the ECM after synthesis, we had to use a dot blot to be able to detect the small amounts of Col I and thus verify the the upregulation of Col I expression in the conditioned media of our cell line. TGF $\beta 1$ did not only induce the expression of ECM components Col I and FN, but also of the growth factors CTGF and TGF $\beta 1$ itself, thus establishing an autocrine loop, which may result in the perpetuation of the fibrotic process. This autocrine stimulation of PSC was also demonstrated by Shek et $a l^{47}$ pinpointing the central role PSC play in the development of pancreatic fibrosis. Taken together, the immortalized PSC retain the basic characteristics of activated PSC, as expression of marker protein and responsiveness to factors implicated in pancreatic fibrosis.

Activation of HSC is dependent not only on cytokines and growth factors but also on the growth substratum. Culture on Col I gels, the most abundant collagen produced by stellate cells during fibrosis, stimulates activation of HSC, whereas cultivation on a reconstituted basement membrane (Matrigel) induces a deactivated state demonstrated by a decrease of Col I and $\alpha$ SMA expression and storage of vitamin $\mathrm{A}$ in lipid droplets. ${ }^{34,52}$ Moreover, treatment of activated HSC with NAC has been reported to induce a quiescent state with a decreased matrix production. ${ }^{36}$ In order to analyze if the same proves to be true for PSC and to test the usefulness of our immortalized cell line, we cultured the immortalized PSC and cultureactivated human PSC as a control on a layer of Matrigel with concomitant NAC treatment for up to 10 days. During this Matrigel cultivation, the PSC lost their myofibroblastic morphology and regained the ability to store vitamin A in lipid vesicles, a feature of nonactivated native PSC. ${ }^{8,9}$ This vitamin A storage may not only be a mere feature of quiescent PSC but functionally contribute to the maintenance of this state, as Jaster et $a l^{53}$ have shown, that retinoic acids through the binding to their nuclear receptors are able to partially block the activation of PSC. In the immortalized PSC expression of Col I, TGF $\beta 1$ and CTGF were downregulated by culture on Matrigel compared to cultivation on plain tissue culture plates, reminiscent of the expression pattern in not-activated PSC. . $^{8,9,15,47,54}$
Matrigel cultivation of culture-activated PSC markedly downregulated the activation markers $\alpha S M A$ and $C T G F$, while upregulating GFAP, but did not change Col I expression. In HSC, GFAP expression is a marker of quiescent cells and is lost during in vitro activation of the cells. ${ }^{44,55}$ Thus, besides the downregulation of the activation marker $\alpha S M A$, the increase in GFAP expression represents additional evidence for the deactivated state induced by this Matrigel cultivation. This effect of matrix on PSC activation is seemingly due to the engagement of different integrins. While there are a few studies on integrins on HSC, ${ }^{56-58}$ nothing is published concerning the role of integrins in the activation process in PSC. The FN receptor ( $\alpha 5 \beta 1$ integrin) is increasingly expressed during activation of HSC and binding to its ligand in the ECM induces activation of multiple kinase pathways and collagen synthesis. ${ }^{59}$ Integrin $\alpha \mathrm{v} \beta 3$, a receptor for FN or vitronectin, regulates proliferation and apoptosis of HSC. ${ }^{60}$ The main components of Matrigel, laminin and Col IV, are ligands for several $\beta 1$ integrins, and antagonizing this integrin consequently inhibited adhesion of HSC to Matrigel. ${ }^{52}$

Simultaneous treatment with the antioxidant NAC further decreased $\alpha S M A$ and $C T G F$ expression to nearly undetectable levels, and downregulated Col I expression. These findings are supported by the known participation of reactive oxygen species in the activation process of stellate cells. ${ }^{61,62}$ Also treatment of primary human PSC grown on plain TC plates with NAC induced a decrease of $\alpha S M A$, but to a smaller extent than did Matrigel cultivation. NAC reduced CTGF expression to similar levels as Matrigel cultivation, but had no effect on GFAP and WAF1 expression. However, in contrast to Matrigel cultivation, NAC treatment was able to decrease Col I expression.

Treatment of primary human PSC cultured on tissue culture plates with NAC resulted in a modest but significant decrease of the proliferation of the cells, and this effect was significantly enhanced when the cells were grown on Matrigel. Cultivation of the cells on Matrigel alone without NAC treatment had no effect on the proliferation of the cells.

There are several possible mechanisms by which NAC induces the antiproliferative and deactivation effects observed in this study. NAC has been shown to cause proteolysis of the extracellular domain of PDGF receptor $\beta$ and in this way may disrupt the mitogenic PDGF signal transduction in activated HSC. ${ }^{63}$ Moreover, NAC was able to block ethanolinduced activation of AP-1 complexes and MAP kinases of PSC, thus disturbing pathways responsible for the proliferation and activation of PSC. ${ }^{62,64}$ In HSC, the antiproliferative effect of NAC was accompanied by an increase of the cell cycle inhibitor Cip1, ${ }^{36}$ whereas in our study no such induction was detectable. Either we just missed the time of Cip1 induction, as we analyzed our cells after several days of treatment in contrast to the $24 \mathrm{~h}$ 
incubation used in the above mentioned paper, or NAC uses different inhibitory molecules to exert its antiproliferative effect in activated PSC.

This deactivation may represent an important mechanism mediating recovery from fibrosis observed during the regeneration phase following acute pancreatitis in experimental animal models. ${ }^{65,66}$

In conclusion, we were able to establish an immortal cell line from human pancreas, which is phenotypically and functionally indistinguishable from primary activated PSC with respect to the expression of stellate cell markers (vimentin, $\alpha \mathrm{SMA}$ and GFAP) and their response to TGF $\beta 1$ and PDGF treatment. Importantly, we were able to demonstrate that besides soluble factors, the matrix surrounding PSC plays a pivotal role in the maintenance of the activation process of PSC, as cultivation of activated PSC on a reconstituted basement membrane plus treatment with NAC was able to deactivate the cells, thus pointing to the possibility of an antifibrosis therapy in chronic pancreatitis. Moreover, we were able to show that our immortalized PSC are instrumental in analyzing the pathomechanisms implicated in pancreatic fibrosis.

\section{Acknowledgements}

We thank Sarina Löffler, Fritz Behne and Swetlana Sander-Naderi for technical assistance and Inaam Nakchbandi for helpful discussion and critical review of the manuscript. This work was in part supported by a grant of the research program 'pathogenic tumor-host interactions' of the Medical Faculty of Mannheim and a grant of the Deutsche Forschungsgemeinschaft (German Research Foundation, Lo431/9-1).

\section{References}

1 Kennedy RH, Bockman DE, Uscanga L, et al. Pancreatic extracellular matrix alterations in chronic pancreatitis. Pancreas 1987;2:61-72.

2 DiMagno EP. A short, eclectic history of exocrine pancreatic insufficiency and chronic pancreatitis. Gastroenterology 1993;104:1255-1262.

3 Löhr M, Schmidt C, Ringel J, et al. Transforming growth factor-beta1 induces desmoplasia in an experimental model of human pancreatic carcinoma. Cancer Res 2001;61:550-555.

4 Klöppel G. Cancer of the pancreas: Morphological and biological aspects. In: Preece PE, Cuschieri A, Rosin RD (eds). Cancer of the Bile Ducts and Pancreas. Saunders: Philadelphia, 1989; 125-138.

5 Friedman SL, Bissell DM. Hepatic fibrosis: new insights into pathogenesis. Hosp Pract (Off Ed) 1990;25: 43-50.

6 Blomhoff R, Wake K. Perisinusoidal stellate cells of the liver: important roles in retinol metabolism and fibrosis. FASEB J 1991;5:271-277.

$7 \mathrm{Li} \mathrm{D}$, Friedman SL. Liver fibrogenesis and the role of hepatic stellate cells: new insights and prospects for therapy. J Gastroenterol Hepatol 1999;14:618-633.
8 Apte MV, Haber PS, Applegate TL, et al. Periacinar stellate shaped cells in rat pancreas: identification, isolation, and culture. Gut 1998;43:128-133.

9 Bachem MG, Schneider E, Gross H, et al. Identification, culture, and characterization of pancreatic stellate cells in rats and humans. Gastroenterology 1998; 115:421-432.

10 Haber PS, Keogh GW, Apte MV, et al. Activation of pancreatic stellate cells in human and experimental pancreatic fibrosis. Am J Pathol 1999;155:1087-1095.

11 Apte MV, Haber PS, Darby SJ, et al. Pancreatic stellate cells are activated by proinflammatory cytokines: implications for pancreatic fibrogenesis. Gut 1999;44: 534-541.

12 Yen TW, Aardal NP, Bronner MP, et al. Myofibroblasts are responsible for the desmoplastic reaction surrounding human pancreatic carcinomas. Surgery 2002; 131:129-134.

13 Zimmermann A, Gloor B, Kappeler A, et al. Pancreatic stellate cells contribute to regeneration early after acute necrotising pancreatitis in humans. Gut 2002;51: $574-578$.

14 Watari N, Hotta Y, Mabuchi Y. Morphological studies on a vitamin A-storing cell and its complex with macrophage observed in mouse pancreatic tissues following excess vitamin A administration. Okajimas Folia Anat Jpn 1982;58:837-858.

15 Schneider E, Schmid-Kotsas A, Zhao J, et al. Identification of mediators stimulating proliferation and matrix synthesis of rat pancreatic stellate cells. Am J Physiol Cell Physiol 2001;281:C532-C543.

16 Mews P, Phillips P, Fahmy R, et al. Pancreatic stellate cells respond to inflammatory cytokines: potential role in chronic pancreatitis. Gut 2002;50:535-541.

17 Luttenberger T, Schmid-Kotsas A, Menke A, et al. Platelet-derived growth factors stimulate proliferation and extracellular matrix synthesis of pancreatic stellate cells: implications in pathogenesis of pancreas fibrosis. Lab Invest 2000;80:47-55.

18 Kato Y, Inoue H, Fujiyama Y, et al. Morphological identification of and collagen synthesis by periacinar fibroblastoid cells cultured from isolated rat pancreatic acini. J Gastroenterol 1996;31:565-571.

19 Kruse ML, Hildebrand PB, Timke C, et al. Isolation, long-term culture, and characterization of rat pancreatic fibroblastoid/stellate cells. Pancreas 2001;23:49-54.

20 Sparmann G, Hohenadl C, Tornoe J, et al. Generation and characterization of immortalized rat pancreatic stellate cells. Am J Physiol Gastrointest Liver Physiol 2004;287:G211-G219.

21 Masamune A, Satoh M, Kikuta K, et al. Establishment and characterization of a rat pancreatic stellate cell line by spontaneous immortalization. World J Gastroenterol 2003;9:2751-2758.

22 Satoh M, Masamune A, Sakai Y, et al. Establishment and characterization of a simian virus 40 -immortalized rat pancreatic stellate cell line. Tohoku J Exp Med 2002;198:55-69.

23 Jesnowski R, Müller P, Schareck W, et al. Immortalized pancreatic duct cells in vitro and in vivo. Ann NY Acad Sci 1999;880:50-65.

24 Löhr M, Müller P, Zauner I, et al. Immortalized bovine pancreatic duct cells become tumorigenic after transfection with mutant k-ras. Virchows Arch 2001;438: 581-590.

25 Macera-Bloch L, Houghton J, Lenahan M, et al. Termination of lifespan of SV40-transformed human 
fibroblasts in crisis is due to apoptosis. J Cell Physiol 2002;190:332-344.

26 Loghman-Adham M, Nauli SM, Soto CE, et al. Immortalized epithelial cells from human autosomal dominant polycystic kidney cysts. Am J Physiol Renal Physiol 2003;285:F397-F412.

27 Neufeld DS, Ripley S, Henderson A, et al. Immortalization of human fibroblasts transformed by origindefective simian virus 40. Mol Cell Biol 1987;7: 2794-2802.

28 Lundberg AS, Randell SH, Stewart SA, et al. Immortalization and transformation of primary human airway epithelial cells by gene transfer. Oncogene 2002;21: 4577-4586.

29 Jesnowski R, Liebe S, Löhr M. Increasing the transfection efficacy and subsequent long-term culture of resting human pancreatic duct epithelial cells. Pancreas 1998;17:262-265.

30 Southern PJ, Berg P. Transformation of mammalian cells to antibiotic resistance with a bacterial gene under control of the SV40 early region promoter. J Mol Appl Genet 1982;1:327-341.

31 Jesnowski R, Backhaus C, Ringel J, et al. Ribosomal highly basic $23-\mathrm{kDa}$ protein as a reliable standard for gene expression analysis. Pancreatology 2002;2:421-424.

32 Trautmann B, Schlitt HJ, Hahn EG, et al. Isolation, culture, and characterization of human pancreatic duct cells. Pancreas 1993;8:248-254.

33 Ringel J, Jesnowski R, Schmidt C, et al. CD44 in normal human pancreas and pancreatic carcinoma cell lines. Teratog Carcinog Mutagen 2001;21:97-106.

34 Sohara N, Znoyko I, Levy MT, et al. Reversal of activation of human myofibroblast-like cells by culture on a basement membrane-like substrate. J Hepatol 2002;37:214-221.

35 Kawada N, Seki S, Inoue M, et al. Effect of antioxidants, resveratrol, quercetin, and $N$-acetylcysteine, on the functions of cultured rat hepatic stellate cells and Kupffer cells. Hepatology 1998;27:1265-1274.

36 Kim KY, Rhim T, Choi I, et al. N-acetylcysteine induces cell cycle arrest in hepatic stellate cells through its reducing activity. J Biol Chem 2001;276:40591-40598.

37 Small MB, Hubbard K, Pardinas JR, et al. Maintenance of telomeres in SV40-transformed pre-immortal and immortal human fibroblasts. J Cell Physiol 1996; 168:727-736.

38 Jha KK, Banga S, Palejwala V, et al. SV40-mediated immortalization. Exp Cell Res 1998;25:245:1-245:7.

$39 \mathrm{Xu}$ L, Hui AY, Albanis E, et al. Human hepatic stellate cell lines, LX-1 and LX-2: new tools for analysis of hepatic fibrosis. Gut 2005;54:142-151.

40 Delgado JP, Parouchev A, Allain JE, et al. Long-term controlled immortalization of a primate hepatic progenitor cell line after Simian virus 40 T-antigen gene transfer. Oncogene 2005;24:541-551.

41 Fauth C, O'Hare MJ, Lederer G, et al. Order of genetic events is critical determinant of aberrations in chromosome count and structure. Genes Chromosomes Cancer 2004;40:298-306.

42 Zhang H, Tsao SW, Jin C, et al. Sequential cytogenetic and molecular cytogenetic characterization of an SV40T-immortalized nasopharyngeal cell line transformed by Epstein-Barr virus latent membrane protein-1 gene. Cancer Genet Cytogenet 2004;150: 144-152.

43 Davies BR, Steele IA, Edmondson RJ, et al. Immortalisation of human ovarian surface epithelium with telomerase and temperature-sensitive SV40 large T antigen. Exp Cell Res 2003;288:390-402.

44 Knittel T, Kobold D, Saile B, et al. Rat liver myofibroblasts and hepatic stellate cells: different cell populations of the fibroblast lineage with fibrogenic potential. Gastroenterology 1999;117:1205-1221.

45 Hocevar BA, Howe PH. Mechanisms of TGF-betainduced cell cycle arrest. Miner Electrolyte Metab 1998;24:131-135.

46 Donovan J, Slingerland J. Transforming growth factorbeta and breast cancer: Cell cycle arrest by transforming growth factor-beta and its disruption in cancer. Breast Cancer Res 2000;2:116-124.

47 Shek FW, Benyon RC, Walker FM, et al. Expression of transforming growth factor-beta 1 by pancreatic stellate cells and its implications for matrix secretion and turnover in chronic pancreatitis. Am J Pathol 2002; 160:1787-1798.

48 Ohnishi H, Miyata T, Yasuda H, et al. Distinct roles of Smad2-, Smad3-, and ERK-dependent pathways in transforming growth factor-beta1 regulation of pancreatic stellate cellular functions. J Biol Chem 2004; 279:8873-8878.

49 Shen H, Huang GJ, Gong YW. Effect of transforming growth factor beta and bone morphogenetic proteins on rat hepatic stellate cell proliferation and trans-differentiation. World J Gastroenterol 2003;9: 784-787.

50 Yang C, Zeisberg M, Mosterman B, et al. Liver fibrosis: insights into migration of hepatic stellate cells in response to extracellular matrix and growth factors. Gastroenterology 2003;124:147-159.

51 Le Pabic H, Bonnier D, Wewer UM, et al. ADAM12 in human liver cancers: TGF-beta-regulated expression in stellate cells is associated with matrix remodeling. Hepatology 2003;37:1056-1066.

52 Gaca MD, Zhou X, Issa R, et al. Basement membranelike matrix inhibits proliferation and collagen synthesis by activated rat hepatic stellate cells: evidence for matrix-dependent deactivation of stellate cells. Matrix Biol 2003;22:229-239.

53 Jaster R, Hilgendorf I, Fitzner B, et al. Regulation of pancreatic stellate cell function in vitro: biological and molecular effects of all-trans retinoic acid. Biochem Pharmacol 2003;66:633-641.

54 Phillips PA, McCarroll JA, Park S, et al. Rat pancreatic stellate cells secrete matrix metalloproteinases: implications for extracellular matrix turnover. Gut 2003; 52:275-282.

55 Buniatian GH. Stages of activation of hepatic stellate cells: effects of ellagic acid, an inhibiter of liver fibrosis, on their differentiation in culture. Cell Prolif 2003;36:307-319.

56 Carloni V, Romanelli RG, Pinzani M, et al. Expression and function of integrin receptors for collagen and laminin in cultured human hepatic stellate cells. Gastroenterology 1996;110:1127-1136.

57 Zhou X, Zhang Y, Zhang J, et al. Expression of fibronectin receptor, integrin alpha 5 beta 1 of hepatic stellate cells in rat liver fibrosis. Chin Med J (England) 2000;113:272-276.

58 Levine D, Rockey DC, Milner TA, et al. Expression of the integrin alpha8beta1 during pulmonary and hepatic fibrosis. Am J Pathol 2000;156:19271935.

59 Milliano MT, Luxon BA. Initial signaling of the fibronectin receptor (alpha5beta1 integrin) in hepatic 
stellate cells is independent of tyrosine phosphorylation. J Hepatol 2003;39:32-37.

60 Zhou X, Murphy FR, Gehdu N, et al. Engagement of alphavbeta3 integrin regulates proliferation and apoptosis of hepatic stellate cells. J Biol Chem 2004;279: 23996-24006.

61 Apte MV, Phillips PA, Fahmy RG, et al. Does alcohol directly stimulate pancreatic fibrogenesis? Studies with rat pancreatic stellate cells. Gastroenterology 2000;118:780-794.

62 Masamune A, Kikuta K, Satoh M, et al. Alcohol activates activator protein-1 and mitogen-activated protein kinases in rat pancreatic stellate cells. J Pharmacol Exp Ther 2002;302:36-42.

63 Okuyama H, Shimahara Y, Kawada N, et al. Regulation of cell growth by redox-mediated extracellular proteo- lysis of platelet-derived growth factor receptor beta. J Biol Chem 2001;276:28274-28280.

64 McCarroll JA, Phillips PA, Park S, et al. Pancreatic stellate cell activation by ethanol and acetaldehyde: is it mediated by the mitogen-activated protein kinase signaling pathway? Pancreas 2003;27:150-160.

65 Demols A, Van Laethem JL, Quertinmont E, et al. Endogenous interleukin-10 modulates fibrosis and regeneration in experimental chronic pancreatitis. Am J Physiol Gastrointest Liver Physiol 2002;282: G1105-G1112.

66 Neuschwander-Tetri BA, Bridle KR, Wells LD, et al. Repetitive acute pancreatic injury in the mouse induces procollagen alpha1(I) expression colocalized to pancreatic stellate cells. Lab Invest 2000;80: $143-150$ 